\title{
On the Mechanism of the Copper-Catalyzed Enantioselective 1,4-Addition of Grignard Reagents to $\alpha, \beta$-Unsaturated Carbonyl Compounds
}

Syuzanna R. Harutyunyan, Fernando López, Wesley R. Browne, Arkaitz Correa, Diego Peña, Ramon Badorrey, Auke Meetsma, Adriaan J. Minnaard,* Ben L. Feringa*

Department of Organic Chemistry and Molecular Inorganic Chemistry, Stratingh Institute, University of Groningen, Nijenborgh 4, 9747 AG, Groningen, The Netherlands

\section{E-mail: B.L.Feringa@ rug.nl}

General. Chiral ligands L1, L2 were gifted by Solvias (Basel). Aliphatic enones, CuCl, CuI, and $\mathrm{CuBr} \cdot \mathrm{SMe}_{2}$ were purchased from Aldrich or Acros, and used without further purification. MeLi and Grignard reagents ( $\mathrm{MeMgBr}, \mathrm{MeMgI}, \mathrm{MeMgCl}$, EtMgBr, EtMgCl, EtMgI) were purchased from Aldrich or prepared from the corresponding alkyl halides and magnesium turnings in $\mathrm{Et}_{2} \mathrm{O}$ following standard procedures. Grignard reagents were titrated using $s$-BuOH and catalytic amounts of 1,10 phenanthroline. ${ }^{t} \mathrm{BuOMe}$ was purchased as anhydrous grade, stored under $4 \AA \hat{\mathrm{MS}}$ and used without further purification. Dialkylmagnesium compounds $\left(\mathrm{Me}_{2} \mathrm{Mg}, \mathrm{Et}_{2} \mathrm{Mg}\right)$ were prepared by stirring akylmagnesium bromides with equimolar amount of dioxane following standard procedures. ${ }^{\text {la,b }}$ Trans$\mathbf{7}^{1 \mathrm{c}}$, cis-8 $^{1 \mathrm{~d}}$, cis-9-11 ${ }^{1 \mathrm{e}}$ were prepared according to the literature procedures. All the solvents used were technical grade and distilled from the indicated drying agents: dichloromethane: $\mathrm{P}_{2} \mathrm{O}_{5}$; diethyl ether, tetrahydrofuran, 1,4-dioxane and hexane: $\mathrm{Na}$, benzophenone; $\mathrm{CD}_{2} \mathrm{Cl}_{2}, d_{8}$-THF, $d_{8}$-toluene used for NMR studies were degassed by three freeze-pump-thaw cycles and stored under $\mathrm{N}_{2} .{ }^{1} \mathrm{H} \mathrm{NMR},{ }^{13} \mathrm{C}\left\{{ }^{1} \mathrm{H}\right\} \mathrm{NMR}$, and ${ }^{31} \mathrm{P}\left\{{ }^{1} \mathrm{H}\right\}$ NMR spectra were obtained with Varian VXR500, 400, 300 spectrometer equipped with a $5 \mathrm{~mm} z$-gradient broadband probe. ${ }^{1} \mathrm{H}$ NMR, ${ }^{31} \mathrm{P}$ NMR and ${ }^{13} \mathrm{C}$ NMR spectra were obtained at 499.9 $\mathrm{MHz}, 202.2 \mathrm{MHz}$ and $125.69 \mathrm{MHz}$, respectively. ${ }^{1} \mathrm{H},{ }^{31} \mathrm{P}$ and ${ }^{13} \mathrm{C}$ chemical shifts $(\delta)$ are reported in parts per million (ppm) and were measured relative to the residual solvent peak $\left(\mathrm{CD}_{2} \mathrm{Cl}_{2} \delta=5.30 \mathrm{ppm}\right.$ for hydrogen atoms, $\delta=53.5$ for carbon atoms, $\mathrm{CDCl}_{3}, \delta=7.26 \mathrm{ppm}$ for hydrogen atoms, $\delta=77.0$ for carbon atoms). ${ }^{31} \mathrm{P}$ chemical shifts are referenced to external standard $85 \% \mathrm{H}_{3} \mathrm{PO}_{4}(0 \mathrm{ppm})$. Coupling constants $(J)$ are reported in hertz $(\mathrm{Hz})$. Due to ${ }^{31} \mathrm{P}$ coupling, resonances for certain carbon atoms in the phosphines listed below were observed as doublets. IR spectral data were obtained using a Perkin-Elmer 1600 FTIR spectrometer. Progress of the reaction and conversion were determined by GC-MS (GC,

\footnotetext{
${ }^{1}$ For the synthesis of $\mathrm{R}_{2} \mathrm{Mg}$, see: (a) Tadeusz, F.; Molinski, T. F.; Ireland, C. M. J. Org. Chem. 1989, 54, 4256-4259. (b) von dem Bussche-Hünnefeld, J. L.; Seebach, D. Tetrahedron 1992, 48, 5719-5730. (c) Jia, C; Lu, W.; Kitamura, T.; Fujuwara, Y. Org. Lett., 1999, 1, 2097-2100. (d) Sano, S.; Yokoyama, K.; Shiro, M.; Nagao, Y. Chem. Pharm. Bull. 2002, 50, 706-709. (e) Lewis F.D.; Oxman, J. D.; Gibson, L. L.; Hampsch, H. L.; Quillen S. L. J. Am. Chem. Soc. 1986, $108,3005-3015$.
} 
HP6890: MS HP5973) with HP1 or HP5 columns (Agilent Technollogies, Palo Alto, CA). Enantio- and regioselectivities were determined by capillary GC analysis (HP 6890, Chiraldex G-TA column (30 m x $0.25 \mathrm{~mm})$, CPChiralsil-Dex-CB $(25 \mathrm{~m} \times 0.25 \mathrm{~mm})$ using flame ionization detector (in comparison with authentic samples of racemic 1,2- and 1,4 addition products). Retention times $\left(t_{R}\right)$ and integrated ratios were obtained using Agilent Chemstation Software. Sample injections were made using an HP 6890 Series Auto sample Injector. Optical rotations were measured in $\mathrm{CHCl}_{3}$ on a Perkin Elmer $241 \mathrm{MC}$ polarimeter with a $10 \mathrm{~cm}$ cell (concentration $c$ given in $\mathrm{g} / 100 \mathrm{~mL}$ ). All conjugate addition reactions were performed under nitrogen atmosphere using standard Schlenk techniques. Reaction vessels were flame-dried prior to use. Flash chromatography was performed using Merck $60 \AA 230-400$ mesh silica gel. All organic extracts were dried over $\mathrm{MgSO}_{4}$, filtered, and concentrated under reduced pressure using a rotary evaporator. Absolute configuration of the products was determined by comparison of the sign of an optical rotation with compounds previously published. Electrochemical measurements were carried out on a Model 630B Electrochemical Workstation ( $\mathrm{CH}$ Instruments). Analytic concentrations were typically 0.5 to $1 \mathrm{mM}$ in anhydrous acetonitrile containing $0.1 \mathrm{M} \mathrm{TBAPF}_{6}$. Unless otherwise stated a Teflon shrouded glassy carbon working electrode, a Pt wire auxiliary electrode non-aqueous $\mathrm{Ag} / \mathrm{Ag}+$ ion reference electrode were employed. Reference electrodes were calibrated using decamethylferrocene as internal reference. Solutions were deoxygenated by purging with dry $\mathrm{N}_{2}$ gas prior to the measurement. Cyclic voltammograms were obtained at sweep rates of between $10 \mathrm{mV} \mathrm{s}^{-1}$ to $5 \mathrm{~V} \mathrm{~s}^{-1}$. Redox potentials are $+/-10 \mathrm{mV}$.

Preparation and characterization of $\mathrm{Cu}-$-complexes $^{2}$ 1a, 1b, 1c, 2a and 3. Typical procedure for $\mathrm{Cu}$ bromide complex 1a.

\section{CuBr complex $(R, S)-1 \mathrm{a}$.}
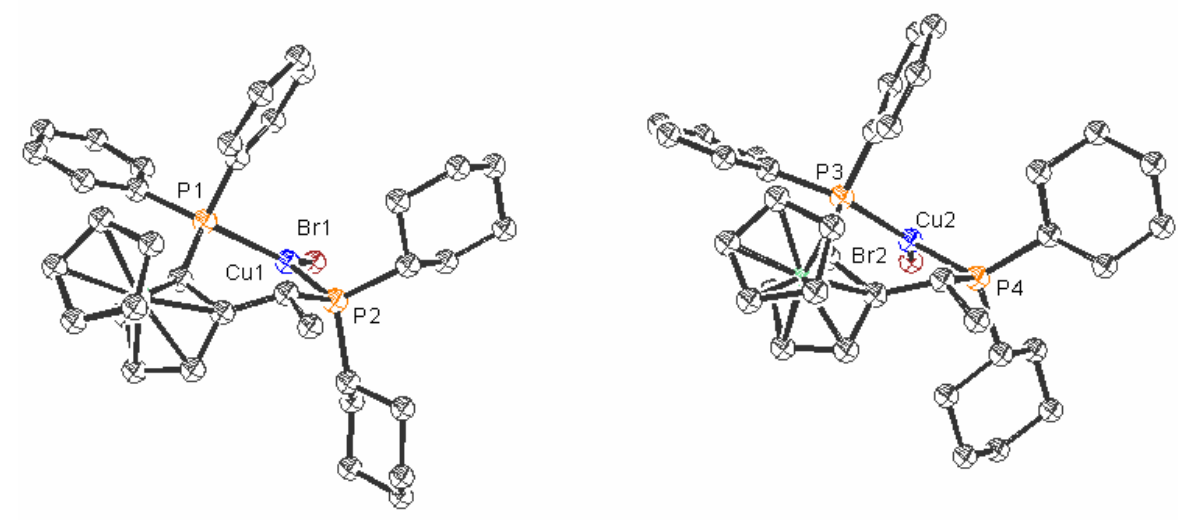

Figure S1. X-ray structure of copper bromide complex $\mathbf{1 a}^{\mathbf{3}}$ ( obtained from $\mathrm{CH}_{3} \mathrm{CN}$ ).

\footnotetext{
${ }^{2}$ (a) ${ }^{1} \mathrm{H},{ }^{13} \mathrm{C}$ and ${ }^{31} \mathrm{P}$ NMR spectra for all compounds are presented in supplementary information 2.

${ }^{3}$ The X-ray structure of $\mathbf{1 a}$ was already published in the short communication in Angew. Chem. Int. Ed. 2005, 44, 27522756. CCDC 261573 contains the supplementary crystallographic data.
} 
A solution of $(R, S)-J o s i P h o s ~(\mathbf{L 1}, 1.68 \mu \mathrm{mol})$ and $\mathrm{CuBr} \cdot \mathrm{SMe}_{2}(1.68 \mu \mathrm{mol})$ in $t \mathrm{BuOMe}(20 \mathrm{~mL})$ in a Schlenk tube was stirred at RT for $30 \mathrm{~min}$. The solvent was removed under vacuum and the resulting orange crude residue was washed with cold pentane to afford $\mathrm{Cu}$-complex as an orange powder (1230 $\mathrm{mg}, 99 \%$ yield $){ }^{1} \mathrm{H}$ NMR $\left(\mathrm{CD}_{2} \mathrm{Cl}_{2}\right.$ at $\left.-60{ }^{0} \mathrm{C}\right) \delta, 7.86(\mathrm{~m}, 4 \mathrm{H}, \mathrm{ArH}), 7.44(\mathrm{~m}, 6 \mathrm{H}, \mathrm{ArH}), 7.16(\mathrm{~m}, 6 \mathrm{H}$, $\operatorname{ArH}), 6.97(\mathrm{~m}, 4 \mathrm{H}), 4.45(\mathrm{~m}, 2 \mathrm{H}, \mathrm{FcH}), 4.36(\mathrm{~m}, 2 \mathrm{H}, \mathrm{FcH}), 4.26(\mathrm{~m}, 2 \mathrm{H}, \mathrm{FcH}), 3.55(\mathrm{~m}, 10 \mathrm{H}, \mathrm{FcH})$, $3.38(\mathrm{~m}, 2 \mathrm{H}, \mathrm{CH}), 1.98(\mathrm{~m}, 4 \mathrm{H}, \mathrm{Cy} H), 1.70-0.92\left(\mathrm{~m}, 46 \mathrm{H}, \mathrm{CyH}\right.$ and $\left.\mathrm{CH}_{3}\right) .{ }^{31} \mathrm{P} \mathrm{NMR}\left(\mathrm{CD}_{2} \mathrm{Cl}_{2}\right.$ at $\left.-60{ }^{0} \mathrm{C}\right)$ $\delta, 8.21(\mathrm{~d}, J=185.6 \mathrm{~Hz}),-24.06(\mathrm{~d}, J=188.9 \mathrm{~Hz}) ;{ }^{13} \mathrm{C} \mathrm{NMR}\left(75.43 \mathrm{MHz}, \mathrm{CD}_{2} \mathrm{Cl}_{2}, \mathrm{RT}\right) \delta, 15.63(\mathrm{bs}$, $\left.2 \mathrm{CH}_{3}\right) ; 25.99\left(\mathrm{~d}, J=10.63 \mathrm{~Hz}, 4 \mathrm{CH}_{2}\right) ; 26.80\left(\mathrm{~m}, 2 \mathrm{CH}_{2}, 2 \mathrm{CH}\right) ; 27.34\left(\mathrm{~d}, J=8.19 \mathrm{~Hz}, 2 \mathrm{CH}_{2}\right) ; 27.76(\mathrm{~d}, J$ $\left.=13.74 \mathrm{~Hz}, 2 \mathrm{CH}_{2}\right) ; 28.93\left(\mathrm{~d}, J=5.59 \mathrm{~Hz}, 2 \mathrm{CH}_{2}\right) ; 29.24\left(\mathrm{~d}, J=6.78 \mathrm{~Hz}, 2 \mathrm{CH}_{2}\right) ; 30.00\left(\mathrm{~m}, 4 \mathrm{CH}_{2}\right)$; $31.99(\mathrm{~m}, 4 \mathrm{CH}) ; 32.87\left(\mathrm{~d}, J=9.58 \mathrm{~Hz}, 2 \mathrm{CH}_{2}\right) 69.95(\mathrm{~d}, J=4.19,2 \mathrm{CH}) ; 70.41(\mathrm{~m}, 10 \mathrm{CH}) ; 70.81(\mathrm{~m}$, $2 \mathrm{CH}) ; 73.52$ (d, $J=17.55 \mathrm{~Hz}, 2 \mathrm{C}) ; 94.38(\mathrm{~m}, 2 \mathrm{C}) ; 128.34(\mathrm{~d}, J=8.56 \mathrm{~Hz}, 4 \mathrm{CH}) ; 128.54(\mathrm{~d}, J=10.38$ $\mathrm{Hz}, 4 \mathrm{CH}) ; 129.03(\mathrm{~s}, 2 \mathrm{CH}) ; 130.61(\mathrm{~s}, 2 \mathrm{CH}) ; 132.54$ (d, $J=14.01 \mathrm{~Hz}, 4 \mathrm{CH}) ; 135.12$ (d, J = 17.45 Hz, $4 \mathrm{CH}) ; 135.81(\mathrm{~m}, J=8.01 \mathrm{~Hz}, 4 \mathrm{C}) ;\left([\alpha]_{\mathrm{D}}{ }^{20}=-302\left(c=0.5 \mathrm{CH}_{2} \mathrm{Cl}_{2}\right)\right.$; Elemental analysis $\mathrm{C}_{72} \mathrm{H}_{88} \mathrm{P}_{4} \mathrm{Fe}_{2} \mathrm{Cu}_{2} \mathrm{Br}_{2}$ : calculated C 58.59; $\mathrm{H}$ 6.01; found: C 58.6, H 6.02. ESI-MS $\left(\mathrm{CH}_{2} \mathrm{Cl}_{2}\right)$ : 1472 [M+ $\left.\left(\mathrm{C}_{72} \mathrm{H}_{88} \mathrm{P}_{4} \mathrm{Fe}_{2} \mathrm{Cu}_{2} \mathrm{Br} 2\right), 91\right], 1428\left[\mathrm{M}_{+}-\mathrm{Br}+\mathrm{Cl}\left(\mathrm{C}_{72} \mathrm{H}_{88} \mathrm{P}_{4} \mathrm{Fe}_{2} \mathrm{Cu}_{2} \mathrm{BrCl}\right), 27\right], 1393\left[\mathrm{M}_{+}-\mathrm{Br}\right.$ $\left(\mathrm{C}_{36} \mathrm{H}_{44} \mathrm{P}_{4} \mathrm{Fe}_{2} \mathrm{Cu} 2 \mathrm{Br}\right)$, 100], $736\left[\mathrm{M}_{+}-\mathrm{C}_{36} \mathrm{H}_{44} \mathrm{P}_{2} \mathrm{FeCuBr}\left(\mathrm{C}_{36} \mathrm{H}_{44} \mathrm{P}_{2} \mathrm{FeCuBr}\right), 6\right], 657 \quad\left[\mathrm{M}_{+}-\mathrm{Br}\right.$ $\left.\left(\mathrm{C}_{35} \mathrm{H}_{56} \mathrm{P} 2 \mathrm{FeCu}\right), 11\right]$. All isotopic patterns are in agreement with those of calculated.

CuCl complex $(R, S)$-1b was prepared from $(R, S)-\mathbf{L 1}(0.05 \mathrm{mmol})$ and $\mathrm{CuCl}(0.05 \mathrm{mmol})$ in $3 \mathrm{ml}$ $\mathrm{CH}_{2} \mathrm{Cl}_{2}$, as described above for 1a. ${ }^{1} \mathrm{H} \mathrm{NMR}\left(\mathrm{CD}_{2} \mathrm{Cl}_{2}\right.$ at $\left.-60{ }^{0} \mathrm{C}\right) \delta, 7.86(\mathrm{~m}, 4 \mathrm{H}, \mathrm{ArH}), 7.41(\mathrm{~m}, 6 \mathrm{H}$, $\operatorname{ArH}), 7.13(\mathrm{~m}, 6 \mathrm{H}, \mathrm{ArH}), 6.96(\mathrm{~m}, 4 \mathrm{H}, \mathrm{ArH}), 4.43-3.39(\mathrm{~m}, 16 \mathrm{H}, \mathrm{FcH}), 3.02(\mathrm{~m}, 2 \mathrm{H}, \mathrm{CH}), 1.93-0.72(\mathrm{~m}$, $50 \mathrm{H}, 2 \mathrm{CyH}$ and $\left.2 \mathrm{CH}_{3}\right) .{ }^{13} \mathrm{C} \mathrm{NMR}\left(125.7 \mathrm{MHz}, \mathrm{CD}_{2} \mathrm{Cl}_{2}, \mathrm{RT}\right) \delta, 15.62\left(\mathrm{bs}, 2 \mathrm{CH}_{3}\right) ; 25.95(\mathrm{~d}, J=17.97 \mathrm{~Hz}$, $\left.4 \mathrm{CH}_{2}\right) ; 26.73\left(\mathrm{~m}, 2 \mathrm{CH}_{2}, 2 \mathrm{CH}\right) ; 27.33\left(\mathrm{~d}, J=7.81 \mathrm{~Hz}, 2 \mathrm{CH}_{2}\right) ; 27.68\left(\mathrm{~d}, J=13.66 \mathrm{~Hz}, 2 \mathrm{CH}_{2}\right) ; 28.79(\mathrm{~d}, J$ $\left.=5.38 \mathrm{~Hz}, 2 \mathrm{CH}_{2}\right) ; 29.19\left(\mathrm{~d}, J=6.90 \mathrm{~Hz}, 2 \mathrm{CH}_{2}\right) ; 30.06\left(\mathrm{bs}, 4 \mathrm{CH}_{2}\right) ; 31.85(\mathrm{~m}, 4 \mathrm{CH}) ; 32.91(\mathrm{~d}, J=9.67$ $\left.\mathrm{Hz}, 2 \mathrm{CH}_{2}\right) ; 69.84(\mathrm{~m}, 2 \mathrm{CH}) ; 70.33(\mathrm{~m}, 10 \mathrm{CH}) ; 70.74(\mathrm{~m}, 2 \mathrm{CH}) ; 73.06(\mathrm{~d}, J=28.85 \mathrm{~Hz}, 2 \mathrm{C}) ; 94.41(\mathrm{~m}$, 2C); $128.28(\mathrm{~d}, J=8.09 \mathrm{~Hz}, 4 \mathrm{CH}) ; 128.51(\mathrm{~d}, J=10.23 \mathrm{~Hz}, 4 \mathrm{CH}) ; 128.85(\mathrm{~s}, 2 \mathrm{CH}) ; 130.51(\mathrm{~s}, 2 \mathrm{CH})$; $132.37(\mathrm{~d}, J=14.41 \mathrm{~Hz}, 4 \mathrm{CH}) ; 135.07$ (d, $J=18.47 \mathrm{~Hz}, 4 \mathrm{CH}) ; 135.25$ (s, 2C); 135.49 (s, 2C); ${ }^{31} \mathrm{P}$ NMR $\left(\mathrm{CD}_{2} \mathrm{Cl}_{2}\right.$ at $\left.-60{ }^{0} \mathrm{C}\right) \delta, 7.78(\mathrm{~d}, J=196.4 \mathrm{~Hz}),-24.15(\mathrm{~d}, J=197.0 \mathrm{~Hz}) .\left([\alpha]_{\mathrm{D}}{ }^{20}=-326\left(c=0.5 \mathrm{CH}_{2} \mathrm{Cl}_{2}\right)\right.$; ESI-MS $\left(\mathrm{CH}_{2} \mathrm{Cl}_{2}\right): 1386$ [ $\left.\mathrm{M}^{+}\left(\mathrm{C}_{72} \mathrm{H}_{88} \mathrm{P}_{4} \mathrm{Fe}_{2} \mathrm{Cu}_{2} \mathrm{Cl}_{2}\right), 100\right], 1351\left[\mathrm{M}^{+}-\mathrm{Cl}\left(\mathrm{C}_{72} \mathrm{H} 88{ }_{8} \mathrm{P}_{4} \mathrm{Fe}_{2} \mathrm{Cu}_{2} \mathrm{Cl}\right), 50\right], 694$ $\left[\mathrm{M}^{+}-\mathrm{C}_{36} \mathrm{H}_{44} \mathrm{P}_{2} \mathrm{FeCuCl}\left(\mathrm{C}_{36} \mathrm{H}_{44} \mathrm{P}_{2} \mathrm{FeCuCl}\right)\right.$, 75].All isotopic patterns are in agreement with those of calculated.

CuI complex $(R, S)$-1c was prepared from $(R, S)-\mathbf{L 1}(0.05 \mathrm{mmol})$ and $\mathrm{CuI}(0.05 \mathrm{mmol})$ in $3 \mathrm{ml} \mathrm{CH}_{2} \mathrm{Cl}_{2}$, as described above for 1a. ${ }^{1} \mathrm{H}$ NMR $\left(\mathrm{CD}_{2} \mathrm{Cl}_{2}\right.$ at $\left.-60{ }^{0} \mathrm{C}\right) \delta, 7.87(\mathrm{~m}, 4 \mathrm{H}, \mathrm{ArH}), 7.44(\mathrm{~m}, 6 \mathrm{H}, \mathrm{ArH}), 7.16$ (m, 6H, ArH), $6.98(\mathrm{~m}, 4 \mathrm{H}, \mathrm{ArH}) 4.47$ (m, 2H, FcH), $4.38(\mathrm{~m}, 2 \mathrm{H}, \mathrm{FcH}), 4.28$ (m, 2H, FcH), $3.55(\mathrm{~m}$, $10 \mathrm{H}, \mathrm{FcH}), 3.35(\mathrm{~m}, 2 \mathrm{H}, \mathrm{CH}), 2.05(\mathrm{~m}, 4 \mathrm{H}, \mathrm{CyH}), 1.70-0.73\left(\mathrm{~m}, 46 \mathrm{H}, \mathrm{CyH}\right.$ and $\left.\mathrm{CH}_{3}\right) .{ }^{13} \mathrm{C} \mathrm{NMR}(75.43$ $\left.\mathrm{MHz}, \mathrm{CD}_{2} \mathrm{Cl}_{2}, \mathrm{RT}\right) \delta, 15.061\left(\mathrm{bs}, 2 \mathrm{CH}_{3}\right) ; 25.97\left(\mathrm{~d}, J=10.99 \mathrm{~Hz}, 4 \mathrm{CH}_{2}\right) ; 26.79\left(\mathrm{~m}, 2 \mathrm{CH}_{2}, 2 \mathrm{CH}\right) ; 27.34$ $\left(\mathrm{d}, J=8.01 \mathrm{~Hz}, 2 \mathrm{CH}_{2}\right) ; 27.73\left(\mathrm{~d}, J=13.71 \mathrm{~Hz}, 2 \mathrm{CH}_{2}\right) ; 28.57\left(\mathrm{~d}, J=6.19 \mathrm{~Hz}, 2 \mathrm{CH}_{2}\right) ; 28.92(\mathrm{~d}, J=7.41$ $\left.\mathrm{Hz}, 2 \mathrm{CH}_{2}\right) ; 29.98\left(\mathrm{~d}, J=10.84 \mathrm{~Hz}, 2 \mathrm{CH}_{2}\right) ; 30.22\left(\mathrm{bs}, 2 \mathrm{CH}_{2}\right) ; 31.58(\mathrm{~m}, 2 \mathrm{CH}) ; 32.13(\mathrm{~d}, J=8.34 \mathrm{~Hz}$, $2 \mathrm{CH}) ; 32.67\left(\mathrm{~d}, J=9.72 \mathrm{~Hz}, 2 \mathrm{CH}_{2}\right) 69.87(\mathrm{~d}, J=4.39,2 \mathrm{CH}) ; 70.35(\mathrm{~m}, 10 \mathrm{CH}) ; 70.08(\mathrm{~m}, 2 \mathrm{CH}) ; 73.08$ $(\mathrm{d}, J=28.07 \mathrm{~Hz}, 2 \mathrm{C}) ; 94.16(\mathrm{~m}, 2 \mathrm{C}) ; 128.22(\mathrm{~d}, J=8.28 \mathrm{~Hz}, 4 \mathrm{CH}) ; 128.54(\mathrm{~d}, J=10.24 \mathrm{~Hz}, 4 \mathrm{CH})$; $128.84(\mathrm{~s}, 2 \mathrm{CH}) ; 130.63(\mathrm{~s}, 2 \mathrm{CH}) ; 132.40(\mathrm{~d}, J=13.84 \mathrm{~Hz}, 4 \mathrm{CH}) ; 135.07$ (d, $J=17.45 \mathrm{~Hz}, 4 \mathrm{CH})$; $135.44(\mathrm{~d}, J=8.48 \mathrm{~Hz}, 2 \mathrm{C}) ; 135.79(\mathrm{~d}, J=8.01 \mathrm{~Hz}, 2 \mathrm{C}) ;{ }^{31} \mathrm{P} \mathrm{NMR}\left(\mathrm{CD}_{2} \mathrm{Cl}_{2}\right.$ at $\left.-60{ }^{0} \mathrm{C}\right) \delta, 9.20(\mathrm{~d}, J=$ $184.3 \mathrm{~Hz}),-23.59(\mathrm{~d}, J=180.3 \mathrm{~Hz}) .[\alpha]_{\mathrm{D}}{ }^{20}=-275\left(c=0.5 \mathrm{CH}_{2} \mathrm{Cl}_{2}\right)$; ESI-MS $\left(\mathrm{CH}_{2} \mathrm{Cl}_{2}\right): 1568\left[\mathrm{M}^{+}\right.$ $\left.\left(\mathrm{C}_{72} \mathrm{H}_{88} \mathrm{P}_{4} \mathrm{Fe}_{2} \mathrm{Cu}_{2} \mathrm{I}_{2}\right), 100\right], 1476$ [ $\left.\mathrm{M}^{+}-\mathrm{I}+\mathrm{Cl}\left(\mathrm{C}_{72} \mathrm{H}_{88} \mathrm{P}_{4} \mathrm{Fe}_{2} \mathrm{Cu} 2 \mathrm{ICl}\right), 54\right], 1441$ [ $\mathrm{M}^{+}-\mathrm{I}\left(\mathrm{C}_{72} \mathrm{H}_{88} \mathrm{P}_{4} \mathrm{Fe}_{2} \mathrm{Cu}_{2} \mathrm{I}\right)$, 40], $784\left[\mathrm{M}^{+}-\mathrm{C}_{36} \mathrm{H}_{44} \mathrm{P}_{2} \mathrm{FeCuI}\left(\mathrm{C}_{36} \mathrm{H}_{44} \mathrm{P}_{2} \mathrm{FeCuI}\right)\right.$, 50].All isotopic patterns are in agreement with those of calculated. 


\section{CuBr complex $(S, R)-\mathbf{2 a}$}

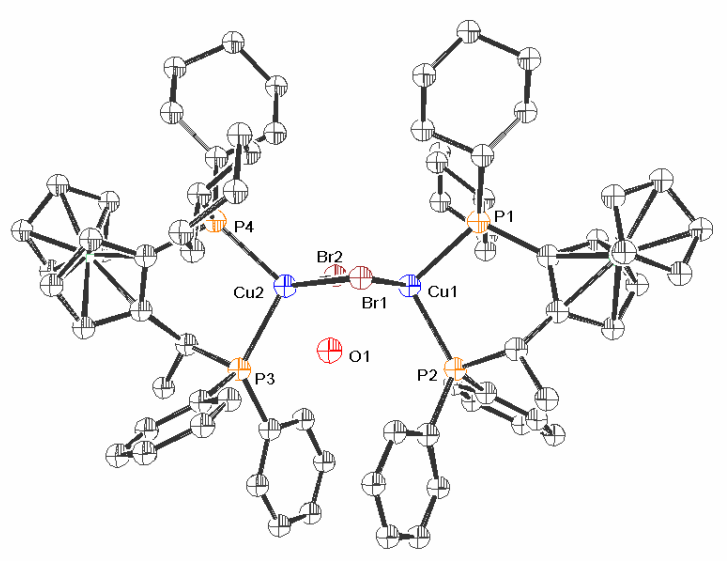

Figure S2. X-ray structure of copper bromide complex $\mathbf{2 a}$ ( obtained from $\mathrm{Et}_{2} \mathrm{O}$ ).

$(S, R)$-2a was prepared from inverted JosiPhos $(S, R)-\mathbf{L} 2$ and $\mathrm{CuBr} \cdot \mathrm{SMe} 2$ in $t \mathrm{BuOMe}$, as described above for 1a: ${ }^{1} \mathrm{H}$ NMR $\delta 7.62(\mathrm{~m}, 4 \mathrm{H}), 7.44(\mathrm{~m}, 4 \mathrm{H}), 7.36-7.18(\mathrm{~m}, 12 \mathrm{H}), 4.31(\mathrm{~m}, 2 \mathrm{H}), 4.27(\mathrm{~m}, 2 \mathrm{H}), 4.20(\mathrm{~m}$, 2H), $4.04(\mathrm{~s}, 10 \mathrm{H}), 3.64(\mathrm{~m}, 2 \mathrm{H}), 2.53(\mathrm{~m}, 2 \mathrm{H}), 2.27(\mathrm{~m}, 4 \mathrm{H}), 1.92-0.83(\mathrm{~m}, 44 \mathrm{H}) .{ }^{13} \mathrm{C}$ NMR $(75.43$ $\left.\mathrm{MHz}, \mathrm{CD}_{2} \mathrm{Cl}_{2}, \mathrm{RT}\right) \delta, 16.92\left(\mathrm{bs}, 2 \mathrm{CH}_{3}\right) ; 26.09$ (d, $\left.J=12.61 \mathrm{~Hz}\right) ; 26.82(\mathrm{~d}, J=10.50 \mathrm{~Hz}) ; 27.22(\mathrm{~m})$; $27.93(\mathrm{~m}) ; 30.13(\mathrm{~m}) ; 31.43(\mathrm{~d}, J=8.68 \mathrm{~Hz}) ; 33.77(\mathrm{~d}, J=8.88 \mathrm{~Hz}) ; 35.3(\mathrm{~m}) ; 39.03(\mathrm{~m}) ; 68.84(\mathrm{~s}$, $2 \mathrm{CH}) ; 69.95(\mathrm{~s}, 8 \mathrm{CH}) ; 70.19(\mathrm{~m}, 2 \mathrm{CH}) ; 73.68(\mathrm{~s}, 2 \mathrm{CH}) ; 74.62(\mathrm{~d}, J=17.99 \mathrm{~Hz}, 2 \mathrm{C}) ; 92.35(\mathrm{~m}, 2 \mathrm{C})$; $128.29(\mathrm{~d}, J=7.41 \mathrm{~Hz}, 4 \mathrm{CH}) ; 128.58(\mathrm{~d}, J=7.00 \mathrm{~Hz}, 4 \mathrm{CH}) ; 129.64(\mathrm{~s}, 2 \mathrm{CH}) ; 19.90$ (s, 2CH); 130.20 $(\mathrm{m}, 2 \mathrm{C}) ; 133.05(\mathrm{~m}, 2 \mathrm{C}) ; 133.49(\mathrm{~m}, 4 \mathrm{CH}) ; 134.47(\mathrm{~m}, 4 \mathrm{CH}) ;{ }^{31} \mathrm{P}$ NMR $\delta-10.95(2 \mathrm{~d}, J=346$ and 180 $\mathrm{Hz}) .[\alpha]_{\mathrm{D}}{ }^{20}=+5\left(c=1 \mathrm{CH}_{2} \mathrm{Cl}_{2}\right)$. Elemental analysis $\mathrm{C}_{72} \mathrm{H}_{88} \mathrm{P}_{4} \mathrm{Fe}_{2} \mathrm{Cu}_{2} \mathrm{Br}_{2}$ : calculated $\mathrm{C} 58.59 ; \mathrm{H}$ 6.01; found: C 58.9, $\mathrm{H}$ 6.34. ESI-MS $\left(\mathrm{CH}_{2} \mathrm{Cl}_{2}\right): 1472$ [M+ $\left.\left(\mathrm{C}_{72} \mathrm{H}_{88} \mathrm{P}_{4} \mathrm{Fe}_{2} \mathrm{Cu}_{2} \mathrm{Br} 2\right), 100\right], 1428\left[\mathrm{M}^{+}-\mathrm{Br}+\mathrm{Cl}\right.$ $\left.\left(\mathrm{C}_{72} \mathrm{H}_{8} \mathrm{P}_{4} \mathrm{Fe}_{2} \mathrm{Cu} 2 \mathrm{BrCl}\right), 55\right], 1393$ [M+ - $\left.\mathrm{Br}\left(\mathrm{C}_{72} \mathrm{H}_{88} \mathrm{P}_{4} \mathrm{Fe}_{2} \mathrm{Cu} 2 \mathrm{Br}\right), 52\right]$

\section{CuBr-heterocomplex $(R, S, S, R)-3$}

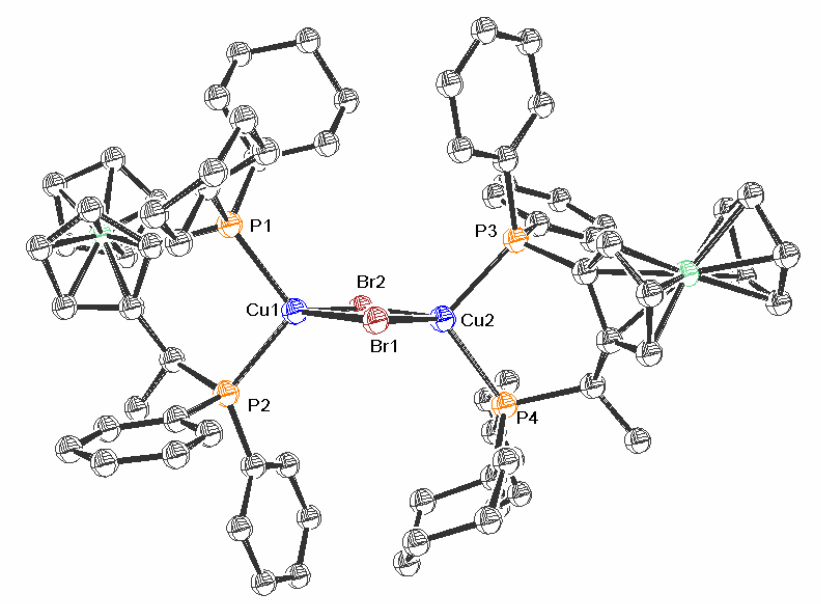


Figure S3. X-ray structure of copper bromide complex 3 ( obtained from hexane/ $\mathrm{CH}_{2} \mathrm{Cl}_{2}$ ).

$(R, S, S, R)-3$ was prepared from $(R, S)-\mathbf{L} \mathbf{1}(0.05 \mathrm{mmol}),(S, R)-\mathbf{L 2}(0.05 \mathrm{mmol})$ and $\mathrm{CuBr} \bullet \mathrm{SMe}_{2}(0.1 \mathrm{mmol})$ in $3 \mathrm{ml} \mathrm{CH} \mathrm{Cl}_{2}$, as described above for 1a. ${ }^{1} \mathrm{H} \mathrm{NMR}\left(\mathrm{CD}_{2} \mathrm{Cl}_{2}\right.$ at $\left.-60{ }^{0} \mathrm{C}\right) \delta, 7.85(\mathrm{~m}, 2 \mathrm{H}, \mathrm{ArH}), 7.30-6.97$ $(\mathrm{m}, 18 \mathrm{H}, \mathrm{ArH}), 4.45(\mathrm{~m}, 1 \mathrm{H}, \mathrm{FcH}), 4.36(\mathrm{~m}, 1 \mathrm{H}, \mathrm{FcH}), 4.20-4.03(\mathrm{~m}, 14 \mathrm{H}, \mathrm{FcH}), 3.56-3.41(\mathrm{~m}, 2 \mathrm{H}, \mathrm{CH})$ 2.32-0.73 (m, 50H, CyH and $\left.\mathrm{CH}_{3}\right) .{ }^{13} \mathrm{C} \mathrm{NMR}^{4} ;{ }^{31} \mathrm{P}-\mathrm{NMR} 8.13(\mathrm{~d}, J=195.2 \mathrm{~Hz}),-11.29(\mathrm{~m}),-24.10(\mathrm{~d}$, $J=194.5 \mathrm{~Hz}) \cdot[\alpha]_{\mathrm{D}}{ }^{20}=-300\left(c=1 \mathrm{CH}_{2} \mathrm{Cl}_{2}\right)$.

\section{NMR experiments, preparation of alkylcopper species. ${ }^{5}$}

Alkylcopper species were prepared in situ (in NMR tube), under nitrogen atmosphere at low temperature $\left(\left(-60{ }^{\circ} \mathrm{C}\right)-\left(-80{ }^{\circ} \mathrm{C}\right)\right)$ by adding $1.5-4$ equiv. of a corresponding freshly prepared Grignard reagent $\left(3 \mathrm{M}\right.$ in $\left.\mathrm{Et}_{2} \mathrm{O}\right)$ to copper bromide complexes in $\mathrm{CD}_{2} \mathrm{Cl}_{2}$. The conversion was monitored by ${ }^{1} \mathrm{H}$ and ${ }^{31} \mathrm{P}$ NMR spectroscopy at $-60{ }^{0} \mathrm{C}$.

Alternatively, alkylcopper species can be prepared in $\mathrm{Et}_{2} \mathrm{O}$. The significant precipitation observed in $\mathrm{Et}_{2} \mathrm{O}$ prevents the use of this solvent for NMR studies and indicates to a low solubility of alkykcopper species formed in $\mathrm{Et}_{2} \mathrm{O}$. However similar species to one obtained in $\mathrm{CD}_{2} \mathrm{Cl}_{2}$ was observed after evaporation of $\mathrm{Et}_{2} \mathrm{O}$ and dissolving the residue in $\mathrm{CD}_{2} \mathrm{Cl}_{2}$.

Note. Excess of Grignard reagent (at least 1.5 equiv) is necessary to achieve complete transformation of the initial copper complex to the alkylcopper species. Decomposition of alkylcopper species in $\mathrm{CH}_{2} \mathrm{Cl}_{2}$ at RT was observed after 30 min with concomitant formation of a black precipitate and a green solution (presumably due to disproportionation to $\mathrm{Cu}(0)$ and $\mathrm{Cu}(\mathrm{II})$ ). However, the solution of alkylcopper species in $\mathrm{CH}_{2} \mathrm{Cl}_{2}$ can be stored in the sealed NMR tube at $-78{ }^{0} \mathrm{C}$ during at least $2 \mathrm{~d}$.

1a + MeMgBr in $\mathbf{C D}_{2} \mathbf{C l}_{2}$ (species A): $1 \mathbf{a}(10 \mathrm{mg}, 13.55 \mathrm{mmol})$ was placed in a flame dried NMR tube (degassed and filled with nitrogen at least three times) under nitrogen atmosphere and $\mathrm{CD}_{2} \mathrm{Cl}_{2}(0.5 \mathrm{~mL})$ was added. After cooling the solution to $\left(-60{ }^{0} \mathrm{C}\right)-\left(-80{ }^{0} \mathrm{C}\right) 1.5-4$ equiv. of $\mathrm{MeMgBr}(3 \mathrm{M})$ were added, leading to instantaneous formation of species A. ${ }^{1} \mathrm{H}$ NMR $\left(\mathrm{CD}_{2} \mathrm{Cl}_{2}\right.$ at $\left.-60{ }^{0} \mathrm{C}\right) \delta, 7.98(\mathrm{~m}, 2 \mathrm{H}, \mathrm{ArH}), 7.39$ $(\mathrm{m}, 3 \mathrm{H}, \mathrm{ArH}), 7.21(\mathrm{~m}, 3 \mathrm{H}, \mathrm{ArH}), 7.06(\mathrm{~m}, 2 \mathrm{H}), 4.52(\mathrm{~m}, 1 \mathrm{H}, \mathrm{FcH}), 4.41(\mathrm{~m}, 1 \mathrm{H}, \mathrm{FcH}), 4.21(\mathrm{~m}, 1 \mathrm{H}$, $\mathrm{FcH})$, 4.06-3.66 (m, 6H, $\mathrm{FcH}, \mathrm{CH}$ signals overlapped with $\mathrm{Et}_{2} \mathrm{O}$ peaks derived from the solution of $\mathrm{MeMgBr}), 2.01-0.36\left(\mathrm{~m}, 25 \mathrm{H}, \mathrm{CyH}, \mathrm{CH}_{3}\right),-0.29$ (s, 3H, $\mathrm{CuMe}$ ), -1.6 (bs, signal corresponding to the excess of MeMgBr). ${ }^{31} \mathrm{P}$ NMR $\left(\mathrm{CD}_{2} \mathrm{Cl}_{2}\right.$ at $\left.-60{ }^{0} \mathrm{C}\right) \delta, 6.41(\mathrm{~d}, J=143.4 \mathrm{~Hz}),-27.03(\mathrm{~d}, J=143.4 \mathrm{~Hz})$.

$1 \mathrm{a}+\mathrm{MeMgBr}$ in THF- $\boldsymbol{d}_{\boldsymbol{8}}$ (species C), was performed as described for $\mathrm{CD}_{2} \mathrm{Cl}_{2} \cdot{ }^{31} \mathrm{P}$ NMR $\left(\mathrm{CD}_{2} \mathrm{Cl}_{2}\right.$ at -60 $\left.{ }^{0} \mathrm{C}\right) \delta, 11.42(\mathrm{~d}, J=167.8 \mathrm{~Hz}),-23.93(\mathrm{~d}, J=167.6 \mathrm{~Hz})$.

$\mathbf{1 a}+\mathrm{MeMgBr}$ in toluene- $\boldsymbol{d}_{\boldsymbol{8}}$ (species A), was performed as described for $\mathrm{CD}_{2} \mathrm{Cl}_{2}:{ }^{31} \mathrm{P} \mathrm{NMR}\left(\mathrm{CD}_{2} \mathrm{Cl}_{2}\right.$ at $\left.-60{ }^{0} \mathrm{C}\right) \delta, 5.99(\mathrm{~d}, J=141.5 \mathrm{~Hz}),-27.45(\mathrm{~d}, J=141.5 \mathrm{~Hz})$.

\footnotetext{
${ }^{4}{ }^{13} \mathrm{C}$ NMR spectrum presented in supplementary information 2.
}

${ }^{5}$ NMR experiments were performed only with copper complexes prepared from ligand L1. Very close chemical shifts corresponding to phosphorus atoms in ${ }^{31} \mathrm{P}$ NMR prevents clear interpretation of the changes observed upon addition of the Grignard reagent. 
1a +2 equiv. MeLi in $\mathbf{C D}_{2} \mathbf{C l}_{2}$ (species C), ${ }^{1} \mathrm{H}$ NMR $\left(\mathrm{CD}_{2} \mathrm{Cl}_{2}\right.$ at $\left.-60{ }^{0} \mathrm{C}\right) \delta, 7.84(\mathrm{~m}, 2 \mathrm{H}, \mathrm{ArH}), 7.45(\mathrm{~m}$, $3 \mathrm{H}, \mathrm{ArH}), 7.15(\mathrm{~m}, 3 \mathrm{H}, \mathrm{ArH}), 6.98(\mathrm{~m}, 2 \mathrm{H}), 4.48(\mathrm{~m}, 1 \mathrm{H}, \mathrm{FcH}), 4.39(\mathrm{~m}, 1 \mathrm{H}, \mathrm{FcH}), 4.31(\mathrm{~m}, 1 \mathrm{H}, \mathrm{FcH})$, 3.57 (s, 5H, $\mathrm{FcH}),\left(\mathrm{CH}\right.$ signals overlapped with $\mathrm{Et}_{2} \mathrm{O}$ peaks derived from $\left.\mathrm{MeMgBr}\right), 1.95$ (bs, $\left.1 \mathrm{H}, \mathrm{CyH}\right)$, 1.72-0.76 (m, 24H, CyH, $\left.\mathrm{CH}_{3}\right),-0.77$ (s, 3H, CuMe), -1.6 (bs, excess of MeMgBr). ${ }^{31} \mathrm{P} \mathrm{NMR}\left(\mathrm{CD}_{2} \mathrm{Cl}_{2}\right.$ at $\left.-60{ }^{\circ} \mathrm{C}\right) \delta, 11.6(\mathrm{~d}, J=163.7 \mathrm{~Hz}),-25.47(\mathrm{~d}, J=163.7 \mathrm{~Hz})$.

1a +3 equiv. MeLi in $\mathrm{CD}_{2} \mathbf{C l}_{2}$ (species $\mathbf{C}$ and $\mathbf{L 1}$ ). Addition of 3 equiv. of MeLi to $1 \mathrm{a}$ led to the species $\mathrm{C}$ with simultaneous formation of free ligand $\mathbf{L 1})$.

1a +4 equiv. MeLi in $\mathbf{C D}_{2} \mathbf{C l}_{2}$. Addition of 4 equiv. of MeLi to $1 \mathrm{a}$ led to a complete release of $\mathrm{Cu}$ from the complex with simultaneous formation of the free ligand $\mathbf{L 1}$ and $\mathrm{Me}_{2} \mathrm{CuLi}$.

Species B: To form species $\mathbf{B}$ the $\mathrm{CD}_{2} \mathrm{Cl}_{2}$ solution of species $\mathbf{A}$ was open to the air for $30 \mathrm{~min}$ at $-60{ }^{0} \mathrm{C}$. This led to a complete transformation to the species B. ${ }^{1} \mathrm{H} \mathrm{NMR}\left(\mathrm{CD}_{2} \mathrm{Cl}_{2}\right.$ at $\left.-60{ }^{0} \mathrm{C}\right) \delta$, 7.96-6.97 (m, $10 \mathrm{H}, \mathrm{ArH}), 4.62-3.36\left(\mathrm{~m}, 9 \mathrm{H}, \mathrm{FcH}, \mathrm{CH}\right.$ signals overlapped with $\mathrm{Et}_{2} \mathrm{O}$ peaks derived from $\mathrm{MeMgBr}$ ), 1.98-0.20 (m, 25H, CyH, $\mathrm{CH}_{3}$, signals overlapped with $\mathrm{Et}_{2} \mathrm{O}$ peaks), -0.32 (s, 3H, CuMe). ${ }^{31} \mathrm{P}$ NMR $\left(\mathrm{CD}_{2} \mathrm{Cl}_{2}\right.$ at $\left.-60{ }^{0} \mathrm{C}\right) \delta, 13.62(\mathrm{~d}, J=153.6 \mathrm{~Hz}),-19.07(\mathrm{~d}, J=153.6 \mathrm{~Hz})$.

\section{Experiments with the additives}

With dioxane. Species $\mathbf{A}$ was prepared as described above from 3 equiv. of $\mathrm{MeMgBr}$ and $\mathbf{1 a}$ in $\mathrm{CD}_{2} \mathrm{Cl}_{2}$ and its complete formation was monitored by NMR. Then 3 equiv. of freshly distilled dioxane was added to the species $\mathbf{A}$ at $-78{ }^{0} \mathbf{C}$ under inert atmosphere and full transformation to the species $\mathbf{C}$ was observed with the concomitant slurry formation (due to formation of dioxane- $\mathrm{MgBr}_{2}$ complex).

With Li-crown-4-ether. Species $\mathbf{C}$ was prepared as described above from 2 equiv. of MeLi and $1 \mathbf{a}$ in $\mathrm{CD}_{2} \mathrm{Cl}_{2}$ and its complete formation was monitored by NMR. Then 2 equiv. of Li-crown-4-ether was added to the species $\mathbf{C}$. at $-78{ }^{0} \mathrm{C}$ under inert atmosphere. No changes were observed in NMR spectra of the species $\mathbf{C}$.

Stoichiometric CA of octenone to the species A, B and C. All reactions were performed in the NMR tube at $-60{ }^{0} \mathrm{C}$ under inert atmosphere and monitored by ${ }^{1} \mathrm{H}$ and ${ }^{31} \mathrm{P}$ NMR.

CA of $\mathbf{A}$ to octenone 5. 1 equiv. of 5 diluted with $0.1 \mathrm{ml}$ of $\mathrm{CD}_{2} \mathrm{Cl}_{2}$ was added to $\mathbf{A}$ prepared by addition of 2 equiv. of $\mathrm{MeMgBr}$ to 1a. Immediate and complete transformation of $\mathbf{A}$ to the complex 1a was observed in ${ }^{31} \mathrm{P} \mathrm{NMR}$, as well as disappearance of signals corresponding to the enone and appearance of the signals corresponding to the double bond of the enolate. The enantioselectivity of the reaction was $92 \%$, similar to the result obtained in catalytic reaction.

CA of $\mathbf{C}$ to octenone 5. The reaction was performed by adding $\mathbf{5}$ at $-70{ }^{0} \mathrm{C}$ to $\mathbf{C}$ formed via addition of 1.5 equiv. of MeLi to $\mathbf{1 a}$ (or 2 equiv. of $\mathrm{MeMgCl}$ to $\mathbf{1 b}$ ). The enantioselectivity was 65 (70\%).

CA of B to octenone 5. Species B formed by storing A in a common NMR tube closed with plastic cup overnight at low temperature without nitrogen atmosphere. The CA reaction was performed by adding 1 equiv. of 5 diluted with $0.1 \mathrm{ml}$ of $\mathrm{CD}_{2} \mathrm{Cl}_{2}$. The enantioselectivity was $89 \%$. 


\section{General Procedure for the enantioselective CA}

In a Schlenk tube equipped with a septum and stirring bar, the $\mathrm{Cu}-$ complex (1a-c, 2a or 3) $(0.037 \mathrm{mmol})$ was dissolved in the corresponding solvent $(1.5 \mathrm{~mL})$ and stirred under argon at room temperature for 5 min. The mixture was then cooled to $-78{ }^{\circ} \mathrm{C}$ and $\mathrm{RMgX}\left(3.0 \mathrm{M}\right.$ solution in $\left.\mathrm{Et}_{2} \mathrm{O}, 0.86 \mathrm{mmol}\right)$ was added. After stirring for $5 \mathrm{~min}$, a solution of enone (enoate) $(0.75 \mathrm{mmol})$ was added at once. After stirring at $-78{ }^{\circ} \mathrm{C}$ ( $1 \mathrm{~h}$ for enones, $5 \mathrm{~h}-12 \mathrm{~h}$ for enoates) $\mathrm{MeOH}(0.25 \mathrm{~mL})$ and $\mathrm{NH}_{4} \mathrm{Cl}(1 \mathrm{M}, 2 \mathrm{~mL})$ were added sequentially, and the mixture was allowed to warm to RT. After extraction with $\mathrm{Et}_{2} \mathrm{O}(1 \mathrm{~mL}, 3 \mathrm{x})$, the combined organic phases were dried and concentrated to a yellow oil, which was used for GC analysis directly.

Note: Alternatively, all reactions can be carried out by using the catalyst (copper complexes) prepared in situ. In both cases, the same conversions and enantioselectivities were obtained.

$(\boldsymbol{R})-(+)-4-M e t h y l o c t a n-2-o n e ~ 6 a^{6 a}$ : from trans-5, $(R, S)-\mathbf{1 a}$ and $\mathrm{MeMgBr}, 98 \% e e,[\alpha]_{\mathrm{D}}{ }^{20}=+4.9(c=$ 0.7); ${ }^{1} \mathrm{H}$ NMR (400 MHz, $\left.\mathrm{CDCl}_{3}\right), \delta 2.39(1 \mathrm{H}, \mathrm{dd}, J=15.8$ and $5.7 \mathrm{~Hz}), 2.20(1 \mathrm{H}, \mathrm{dd}, J=15.9$ and 8.1 $\mathrm{Hz}), 2.11(3 \mathrm{H}, \mathrm{s}), 1.97(1 \mathrm{H}, \mathrm{m}), 1.35-1.20(6 \mathrm{H}, \mathrm{m}), 0.87(6 \mathrm{H}, \mathrm{m}) ;{ }^{13} \mathrm{C} \mathrm{NMR}\left(100.59 \mathrm{MHz} \mathrm{CDCl}_{3}\right)$, $\delta 209.4(\mathrm{C}), 51.3(\mathrm{CH} 2), 36.6(\mathrm{CH} 2), 30.3(\mathrm{CH}), 29.3(\mathrm{CH} 3), 29.1(\mathrm{CH} 2), 22.8(\mathrm{CH} 2), 19.8(\mathrm{CH} 3), 14.0$ (CH3). LRMS (EI) m/z $142(\mathrm{M}+, 27), 127$ (M+ - CH3, 95), 112, 85 (100), 71, 58: HRMS Calcd. for $\mathrm{C}_{9} \mathrm{H}_{18} \mathrm{O}$ 142.13576, found 142.13503. Enantioselectivity determined by chiral GC analysis, CPChiralsil-Dex-CB $(25 \mathrm{~m} \times 0.25 \mathrm{~mm}), 90{ }^{\circ} \mathrm{C}$, retention times: $9.59 / 9.72 \mathrm{~min}$.

(+)-4-(Furan-2-yl)hexan-2-one 12a ${ }^{6 \mathrm{a}}$ : from trans-7, $(R, S)-\mathbf{1 a}$ and EtMgBr, $90 \%$ ee $[\alpha]_{\mathrm{D}}{ }^{20}=+14(c=$ 1.3); ${ }^{1} \mathrm{H}$ NMR (400 MHz, $\left.\mathrm{CDCl}_{3}\right) \delta 7.29(1 \mathrm{H}, \mathrm{m}), 6.26(1 \mathrm{H}, \mathrm{m}), 5.99(1 \mathrm{H}, \mathrm{m}), 3.19(1 \mathrm{H}, \mathrm{m}), 2.78(1 \mathrm{H}$, dd, $J=16.4$ and $7.6 \mathrm{~Hz}), 2.64(1 \mathrm{H}, \mathrm{dd}, J=16.4$ and $6.8 \mathrm{~Hz}), 2.07(3 \mathrm{H}, \mathrm{s}), 1.62(2 \mathrm{H}, \mathrm{m}), 0.83(3 \mathrm{H}, \mathrm{t}, J=$ 7.6 Hz); ${ }^{13} \mathrm{C} \mathrm{NMR}\left(100.59 \mathrm{MHz} \mathrm{CDCl}_{3}\right), \delta 207.7,158.3,141.0,109.9,105.2,45.5,36.0,30.4,26.9$, 11.6; LRMS (EI) m/z 166 (M+,100), 151 (5), 137, 123, 109, 81; HRMS Calcd. for $\mathrm{C}_{10} \mathrm{H}_{14} \mathrm{O}_{2}$ 166.0994, found 166.0999. Enantioselectivity was determined by chiral GC analysis, Chiraldex $\beta$-PM (30 m x 0.25 $\mathrm{mm}$ ), initial temp. $70{ }^{\circ} \mathrm{C}$, initial time $30 \mathrm{~min}$, rate $10^{\circ} \mathrm{C} / \mathrm{min}$, final temp $140{ }^{\circ} \mathrm{C}$; retention times : 33.0 / $34.0 \mathrm{~min}$.

Methyl 3-ethylhexanoate 12b ${ }^{6 \mathrm{~b}}$, from trans-8, $(R, S)$-1a and EtMgBr, ${ }^{1} \mathrm{H} \mathrm{NMR}\left(400 \mathrm{MHz}, \mathrm{CDCl}_{3}\right), \delta \mathrm{d}$ $3.58(\mathrm{~s}, 3 \mathrm{H}), 2.16(\mathrm{~d}, J=6.9 \mathrm{~Hz}, 2 \mathrm{H}), 1.73(\mathrm{~m}, 1 \mathrm{H}), 1.22(\mathrm{~m}, 6 \mathrm{H}), 0.80(\mathrm{~m}, 6 \mathrm{H}) ;{ }^{13} \mathrm{C} \mathrm{NMR}(100.59 \mathrm{MHz}$ $\left.\mathrm{CDCl}_{3}\right), \delta 174.0(\mathrm{C}), 51.2(\mathrm{CH} 3), 38.5(\mathrm{CH} 2), 36.1(\mathrm{CH}), 35.6(\mathrm{CH} 2), 26.2(\mathrm{CH} 2), 19.6(\mathrm{CH} 2), 14.2$ (CH3), $10.6(\mathrm{CH} 3)$; LRMS m/z $158(\mathrm{M}++1,1), 143$ (1), 127 (3), 115 (7), 85 (32), 74 (100); HRMS calcd. for $\mathrm{C}_{9} \mathrm{H}_{18} \mathrm{O}_{2} 158.1307$, found 158.1319 . Enantioselectivity was determined by chiral GC analysis, Chiraldex G-TA column (30 $\mathrm{m}$ x $0.25 \mathrm{~mm}), 60^{\circ} \mathrm{C}$, retention times (min): 20.9 (major) and 21.8 (minor).

(S)-(+)-Methyl 3-phenylpentanoate 12c ${ }^{6 \mathrm{~b}}$ : from trans-9, $(S, R)-2 \mathrm{a}$ and EtMgBr, $[\mathrm{a}]_{\mathrm{D}}{ }^{20}=+18.7(c=1.2)$, ${ }^{1} \mathrm{H}$ NMR $\left(400 \mathrm{MHz}, \mathrm{CDCl}_{3}\right), \delta \mathrm{d} 7.24(\mathrm{~m}, 2 \mathrm{H}), 7.14(\mathrm{~m}, 3 \mathrm{H}), 3.53(\mathrm{~s}, 3 \mathrm{H}), 2.96(\mathrm{~m}, 1 \mathrm{H}), 2.56(\mathrm{~m}, 2 \mathrm{H})$, $1.65(\mathrm{~m}, 1 \mathrm{H}), 1.58(\mathrm{~m}, 1 \mathrm{H}), 0.75(\mathrm{dt}, J=7.3$ and $1.3 \mathrm{~Hz}, 3 \mathrm{H}) ;{ }^{13} \mathrm{C} \mathrm{NMR}\left(100.59 \mathrm{MHz} \mathrm{CDCl}_{3}\right), \delta 172.9$ $(\mathrm{C}), 143.8(\mathrm{C}), 128.3(\mathrm{CH}), 127.4(\mathrm{CH}), 126.3(\mathrm{CH}), 51.4\left(\mathrm{CH}_{3}\right), 43.8(\mathrm{CH}), 41.2\left(\mathrm{CH}_{2}\right), 29.0\left(\mathrm{CH}_{2}\right)$, 11.8 (CH3); LRMS (EI) m/z 192 (M+, 32), 160 (21), 132 (45), 121 (100) 91 (95); HRMS calcd. for

\footnotetext{
${ }^{6}$ (a) For references see supplementary information (a) J. Am. Chem. Soc. 2004, 126, 12784-12785. (b) Angew. Chem. Int.
} Ed. 2005, 44, 2752-2756. 
$\mathrm{C}_{12} \mathrm{H}_{16} \mathrm{O}_{2} 192.1150$, found 192.1153 . Enantioselectivity was determined by chiral GC analysis, Chiraldex G-TA column ( $30 \mathrm{~m} \times 0.25 \mathrm{~mm}$ ), $90^{\circ} \mathrm{C}$, retention times (min): 24.7 (minor) and 25.0 (major).

(+)-Methyl 3-(4-(trifluoromethyl)phenyl)pentanoate, 12d ${ }^{6 \mathrm{~b}}$ : from trans-10, $(S, R)-\mathbf{2 a}$ and EtMgBr, $[\mathrm{a}]_{\mathrm{D}}{ }^{20}=+16.5(c=1.7),{ }^{1} \mathrm{H}$ NMR $\left(400 \mathrm{MHz}, \mathrm{CDCl}_{3}\right), \delta \mathrm{d} 7.49(\mathrm{~d}, J=8.0 \mathrm{~Hz}, 2 \mathrm{H}), 7.24(\mathrm{~d}, J=8.0 \mathrm{~Hz}$, $2 \mathrm{H}), 3.51(\mathrm{~s}, 3 \mathrm{H}), 3.03(\mathrm{~m}, 1 \mathrm{H}), 2.62(\mathrm{dd}, J=15.5$ and $6.7 \mathrm{~Hz}, 1 \mathrm{H}), 2.52(\mathrm{dd}, J=15.5$ and $8.4 \mathrm{~Hz}, 1 \mathrm{H})$, $1.67(\mathrm{~m}, 1 \mathrm{H}), 1.57(\mathrm{~m}, 1 \mathrm{H}), 0.73(\mathrm{t}, J=7.4 \mathrm{~Hz}) ;{ }^{13} \mathrm{C}$ NMR $172.4(\mathrm{C}), 148.1(\mathrm{C}), 128.1(\mathrm{C}), 127.8(\mathrm{CH})$, 125.4 (CH), $123.1(\mathrm{C}), 51.5\left(\mathrm{CH}_{3}\right), 43.6(\mathrm{CH}), 40.8\left(\mathrm{CH}_{2}\right), 29.0\left(\mathrm{CH}_{2}\right), 11.7\left(\mathrm{CH}_{3}\right)$; LRMS m/z $260(\mathrm{M}+$, 23), 241 (24), 200 (51), 189 (72), 159 (100); HRMS calcd. for $\mathrm{C}_{13} \mathrm{H}_{15} \mathrm{~F}_{3} \mathrm{O}_{2}$ 260.1024, found 260.1026. Enantioselectivity was determined by chiral GC analysis, Chiraldex G-TA column (30 m x $0.25 \mathrm{~mm}$ ), $90^{\circ} \mathrm{C}$, retention times (min): 57.5 (minor) and 59.3 (major).

(-)-Methyl-3-(4-methoxy-phenyl)-pentanoate, 12e: from trans-11, $(R, S)-\mathbf{2 a}$ and EtMgBr, $[\mathrm{a}]_{\mathrm{D}}{ }^{20}=-$ $22.8(c=2),{ }^{1} \mathrm{H}$ NMR $\left(400 \mathrm{MHz}, \mathrm{CDCl}_{3}\right), \delta \mathrm{d} 7.08(\mathrm{~d}, J=8.8 \mathrm{~Hz}, 2 \mathrm{H}), 6.83(\mathrm{~d}, J=8.8 \mathrm{~Hz}, 2 \mathrm{H}), 3.78(\mathrm{~s}$, $3 \mathrm{H}), 3.57(\mathrm{~s}, 3 \mathrm{H}), 2.94(\mathrm{~m}, 1 \mathrm{H}), 2.61(\mathrm{dd}, J=16.0$ and $6.8 \mathrm{~Hz}, 1 \mathrm{H}), 2.52(\mathrm{dd}, J=15.2$ and $8.0 \mathrm{~Hz}, 1 \mathrm{H})$, $1.66(\mathrm{~m}, 1 \mathrm{H}), 1.55(\mathrm{~m}, 1 \mathrm{H}), 0.77(\mathrm{t}, J=7.2 \mathrm{~Hz}) ;{ }^{13} \mathrm{C}$ NMR $173.3(\mathrm{C}), 158.3(\mathrm{C}), 136.1(\mathrm{C}), 128.6(\mathrm{CH})$, 114.0 (CH), $55.4\left(\mathrm{CH}_{3}\right), 51.6\left(\mathrm{CH}_{3}\right), 43.3(\mathrm{CH}), 41.7\left(\mathrm{CH}_{2}\right), 29.4\left(\mathrm{CH}_{2}\right), 12.1\left(\mathrm{CH}_{3}\right)$; LRMS (EI) $\mathrm{m} / \mathrm{z}$ $222(\mathrm{M}+, 23), 193$ (47), 149 (100), 121 (40), 91 (20); HRMS calcd. for $\mathrm{C}_{13} \mathrm{H}_{15} \mathrm{~F}_{3} \mathrm{O}_{2}$ 260.1249, found 222.1255. Enantioselectivity was determined by chiral HPLC analysis, Chiralcel OB-H column (99:1 heptane :isopropanol,) retention times (min): 12.3 and 14.5

$(S)$-(+)-Methyl 3-methylpentanoate 14: ${ }^{6 \mathrm{~b}}$ from trans-13, $(R, S)-\mathbf{1 a}$ and EtMgBr; $[\mathrm{a}]_{\mathrm{D}}{ }^{20}=+5.9(c=1)$; ${ }^{1} \mathrm{H}$ NMR $\left(400 \mathrm{MHz}, \mathrm{CDCl}_{3}\right), \delta 3.63(\mathrm{~s}, 3 \mathrm{H}), 2.28(\mathrm{dd}, J=14.7$ and $6.1 \mathrm{~Hz}, 1 \mathrm{H}), 2.09(\mathrm{dd}, J=14.7$ and $8.2 \mathrm{~Hz}, 1 \mathrm{H}), 1.85(\mathrm{~m}, 1 \mathrm{H}), 1.33(\mathrm{~m}, 1 \mathrm{H}), 1.21(\mathrm{~m}, 1 \mathrm{H}), 0.89(\mathrm{~d}, J=6.6 \mathrm{~Hz}, 3 \mathrm{H}), 0.86(\mathrm{t}, J=6.4 \mathrm{~Hz}, 3 \mathrm{H})$; ${ }^{13} \mathrm{C} \mathrm{NMR}_{\left(\mathrm{CDCl}_{3}\right)} \delta 173.7(\mathrm{C}), 51.2\left(\mathrm{CH}_{3}\right), 41.1\left(\mathrm{CH}_{2}\right), 31.8(\mathrm{CH}), 29.2\left(\mathrm{CH}_{2}\right), 19.1\left(\mathrm{CH}_{3}\right), 11.1\left(\mathrm{CH}_{3}\right)$. Enantioselectivity was determined by chiral GC analysis, Chiraldex G-TA column (30 m x $0.25 \mathrm{~mm}$ ), $60{ }^{\circ} \mathrm{C}$, retention times: 6.7 (minor)/ 6.9 (major) min.

\section{Kinetic analysis}

The procedure for determining the rate of the reaction was represented by the reaction under conditions at which the concentrations of $13, \mathrm{EtMgBr}$ and $1 \mathrm{a}$ were $90 \mathrm{mM}, 90 \mathrm{mM}, 0.9 \mathrm{mM}$, respectively, and the temperature was $-87{ }^{\circ} \mathrm{C}$. The reaction was carried out in Schlenk flask under nitrogen in $\mathrm{CH}_{2} \mathrm{Cl}_{2}$. The progress of the reaction was determined by removing aliquots at specific time intervals: the aliquots were hydrolyzed by fast transferring to the cold $\mathrm{MeOH}$ solution. The aliquots were analyzed by gas chromatography (chiral G-TA column) using butyl ether as an internal standard in the reaction mixture.

a) Dependence on catalyst. $0.9 \mathrm{mM}, 1.8 \mathrm{mM}, 2.7 \mathrm{mM}, 3.6 \mathrm{mM}$ solutions of $1 \mathrm{a}$ in $30 \mathrm{ml}$ of $\mathrm{CH}_{2} \mathrm{Cl}_{2}$ were prepared and $40 \mu \mathrm{l}$ of internal standard $\mathrm{Bu}_{2} \mathrm{O}$ was added. The solutions were cooled to $-87^{\circ} \mathrm{C}$ and 1.1 equiv. of $\mathrm{EtMgBr}\left(3 \mathrm{M}\right.$ in $\left.\mathrm{Et}_{2} \mathrm{O}\right)$ was added. After 15 min enone $13(90 \mathrm{mM})$ was added at once. The aliquots were taken every 2-5 min during $4 \mathrm{~h}$ (minimum $80 \%$ conversion was obtained after $4 \mathrm{~h}$ for all the experiments). The analysis was made by plotting $1 / C_{13}$ versus time. The slope obtained from the $1 / \mathrm{C}_{13}$ concentration vs. time (s) was calculated as the reaction rate constant. The determined rate constants are presented in the Table $\mathrm{S} 1$

Table S1. Rate constants for different catalyst concentrations

\begin{tabular}{ccc}
\hline $\mathrm{C}_{1 \mathrm{a}} / \mathrm{mM}$ & $\mathbf{k} / \mathrm{Lmol}^{-1} \mathrm{~s}^{-1}$ & $\mathbf{L n ~} \mathbf{k}$ \\
\hline 9.0 & $1.31 \mathrm{E}-02$ & -4.34 \\
1.8 & $2.43 \mathrm{E}-02$ & -3.72 \\
2.7 & $4.93 \mathrm{E}-02$ & -3.01 \\
3.6 & $6.31 \mathrm{E}-02$ & -2.76 \\
\hline
\end{tabular}




\begin{tabular}{|cc|}
\hline Order $=$ slope & $\mathbf{1 . 1 7 4 4 0 4 1}$ \\
\hline OX & 3.84217988 \\
\hline
\end{tabular}

b) Dependence on EtMgBr. Four stock solutions of $20 \mathrm{mg}(0.027 \mathrm{mmol}) \mathbf{1 a}$ in the mixture of solvents $\mathrm{CH}_{2} \mathrm{Cl}_{2}$ and $\mathrm{Et}_{2} \mathrm{O}$ with the volume (ml) ratio 26/3, 26/2 26/1, 26/0 were prepared and $40 \mu$ of internal standard $\left(\mathrm{Bu}_{2} \mathrm{O}\right)$ was added. The solutions were cooled to $-87{ }^{\circ} \mathrm{C}$ and either $1 \mathrm{~mL}$ (final concentration in reaction solution, $90 \mathrm{mM}), 2 \mathrm{~mL}(180 \mathrm{mM}), 3 \mathrm{~mL}(279 \mathrm{mM})$ or $4 \mathrm{ml}(360 \mathrm{mM})$ of $\mathrm{EtMgBr}(3 \mathrm{M}$, in $\mathrm{Et}_{2} \mathrm{O}$ ) were added to the stock solutions. After $15 \mathrm{~min}$ stirring at constant speed, 13 (1 equiv., 90mM) was added in one addition. The aliquots were taken every 2-5 $\min$ over $4 \mathrm{~h}$. The graph is presented in Figure S4 (The reaction progress was followed by a decrease in the substrate concentration [13], M).

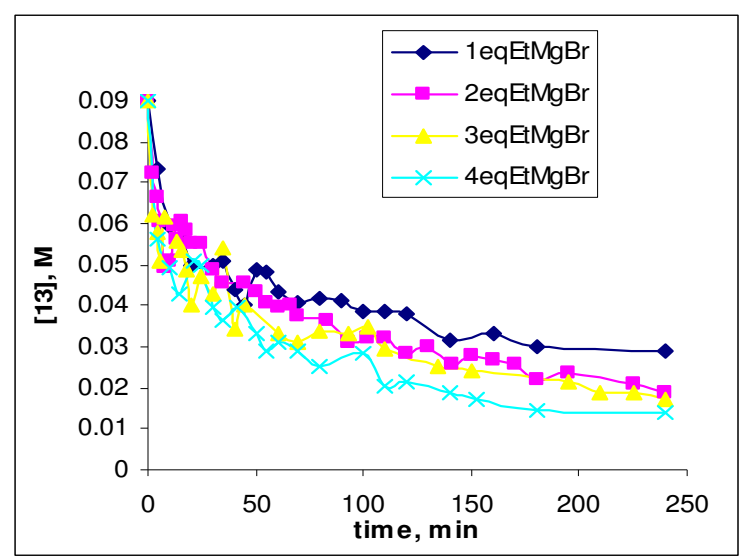

Figure S4 Kinetic data for different concentrations of EtMgBr (1-4 equiv.)

c) Dependence on substrate 13. Four stock solutions of $20 \mathrm{mg}(0.027 \mathrm{mmol}, 0.9 \mathrm{mM}) \mathbf{1 a}$ in $\mathrm{CH}_{2} \mathrm{Cl}_{2}$ were prepared and $40 \mu \mathrm{l}$ of internal standard $\mathrm{Bu}_{2} \mathrm{O}$ was added. The solutions were cooled to $-87{ }^{0} \mathrm{C}$ and $90 \mathrm{mM}$ of $\mathrm{EtMgBr}\left(3 \mathrm{M}\right.$, in $\left.\mathrm{Et}_{2} \mathrm{O}\right)$ was added to the stock solutions. After 15 min stirring at constant speed $90 \mathrm{mM}, 180 \mathrm{mM}, 270 \mathrm{mM}, 360 \mathrm{mM}$ of substrate 13 were added at once. The aliquots were taken every 5 min during $4 \mathrm{~h}$. The graph is presented in Figure S5 (The reaction progress was followed by an increase in the product concentration [14], M).

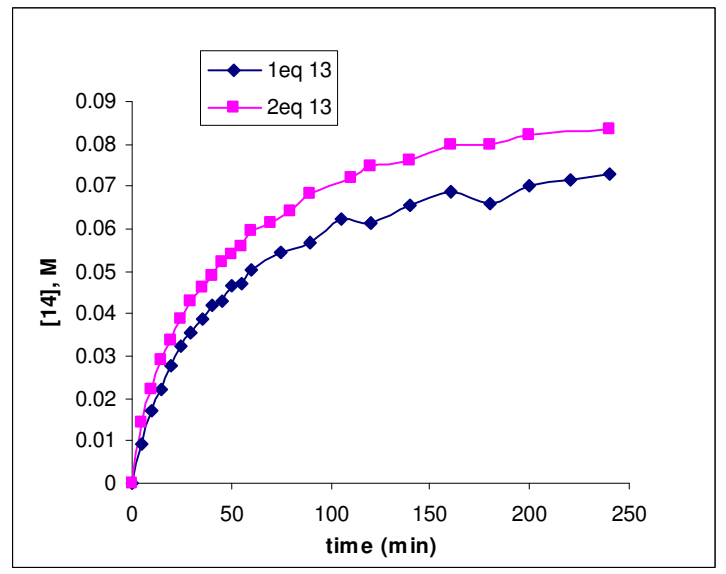

Figure S5 Kinetic data for different concentrations of $\mathbf{1 3}$ (1-2 equiv). 
d) Determination of the thermodynamic parameters. To determine the activation parameters the reactions with the following concentrations of reactants $1390 \mathrm{mM}$, EtMgBr $90 \mathrm{mM}$ and $1 \mathrm{a} 0.9 \mathrm{mM}$ were employed at 4 different temperatures. The analysis was made by plotting $1 / C_{13}$ versus time. The slope obtained from the $1 / C_{13}$ concentration vs. time (s) was calculated as the reaction rate constant. The rate constants obtained are presented in the Table S2, S3

Table S2.

\begin{tabular}{ccccc}
\hline $\mathbf{T}\left({ }^{\mathbf{0}} \mathbf{C}\right)$ & $\mathbf{k} / \mathbf{L m o l}^{\mathbf{- 1}} \mathbf{s}^{-\mathbf{1}}$ & $\mathbf{t}_{\mathbf{1} / 2}(\mathbf{m i n})$ & $\begin{array}{c}\Delta \mathbf{G}^{\#} \\
\left(\mathbf{k c a l . m o l}^{\mathbf{1}}\right)\end{array}$ & $\boldsymbol{\Delta} \mathbf{G}^{\#}\left(\mathbf{k J . m o l} \mathbf{~}^{\mathbf{1}}\right)$ \\
\hline-85.0 & $1.31 \mathrm{E}-02$ & 141.19 & 12.46 & 52.09 \\
-79.0 & $1.96 \mathrm{E}-02$ & 94.18 & 12.72 & 53.15 \\
-72.0 & $3.77 \mathrm{E}-02$ & 48.94 & 12.93 & 54.03 \\
-65.0 & $4.77 \mathrm{E}-02$ & 38.69 & 13.29 & 55.57 \\
\hline
\end{tabular}

Table S3. Thermodynamic parameters.

\begin{tabular}{ccc}
\hline Employed equations for the calculation & $\mathrm{Ea}\left(\mathrm{kJ} \cdot \mathrm{mol}^{-1}\right)$ & 28 \\
from $\Delta G=\Delta H-T \Delta S$ & $\Delta \mathrm{H}^{\#}\left(\mathrm{~kJ}^{-1} \mathrm{~mol}^{-1}\right)$ & 26 \\
from $\Delta G^{\#}=-R T \ln \left(k \cdot h / k_{B} \cdot T\right)$ & $\Delta \mathrm{S}^{\#}\left(\mathrm{~J}^{-1} \mathrm{~K}^{-1} \cdot \mathrm{mol}^{-1}\right)$ & -138 \\
from $k=A \exp (-E a / R T)$ & $\Delta^{\#} \mathrm{G}^{0}\left(20^{\circ} \mathrm{C}\right)\left(\mathrm{kJ} \mathrm{mol}^{-1}\right)$ & 66 \\
from $k=\ln 2 / t_{1 / 2}$ & $\mathrm{k}^{0}\left(20^{\circ} \mathrm{C}\right)\left(\mathrm{mol}^{-1} \cdot \mathrm{s}^{-1}\right)$ & 4.8 \\
& $\mathrm{t}_{1 / 2}{ }^{0}\left(20^{\circ} \mathrm{C}\right)(\mathrm{s})$ & 23.3 \\
\hline
\end{tabular}

\section{Electrochemistry}

The requirement for sufficient electrolyte to be present to allow conductivity requires that the control experiments are carried out to ensure that the catalytic properties of the system remain largely unperturbed with regard to both regio- and enatioselectivity. Although significantly lower enantioselectivity was obtained, it is unlikely that catalyst present in the electrolyte solution is the different to that present in the absence of $\mathrm{TBAPF}_{6}$.

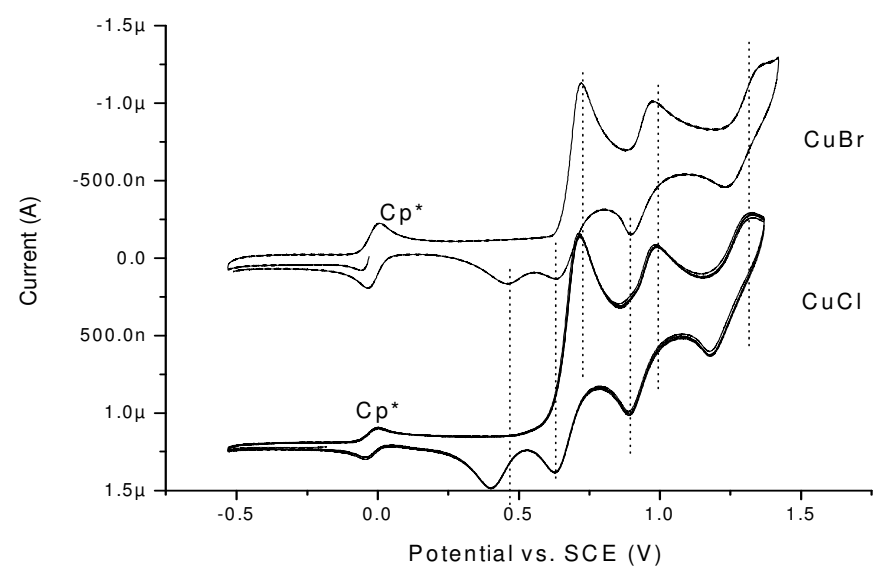

Figure S6. 2a and $\mathrm{Cl}$ analogue $(0.1 \mathrm{M} \mathrm{TBABr})$ at $-80{ }^{\circ} \mathrm{C}$. scan rate $=25 \mathrm{mV} \mathrm{s}^{-1}$. 


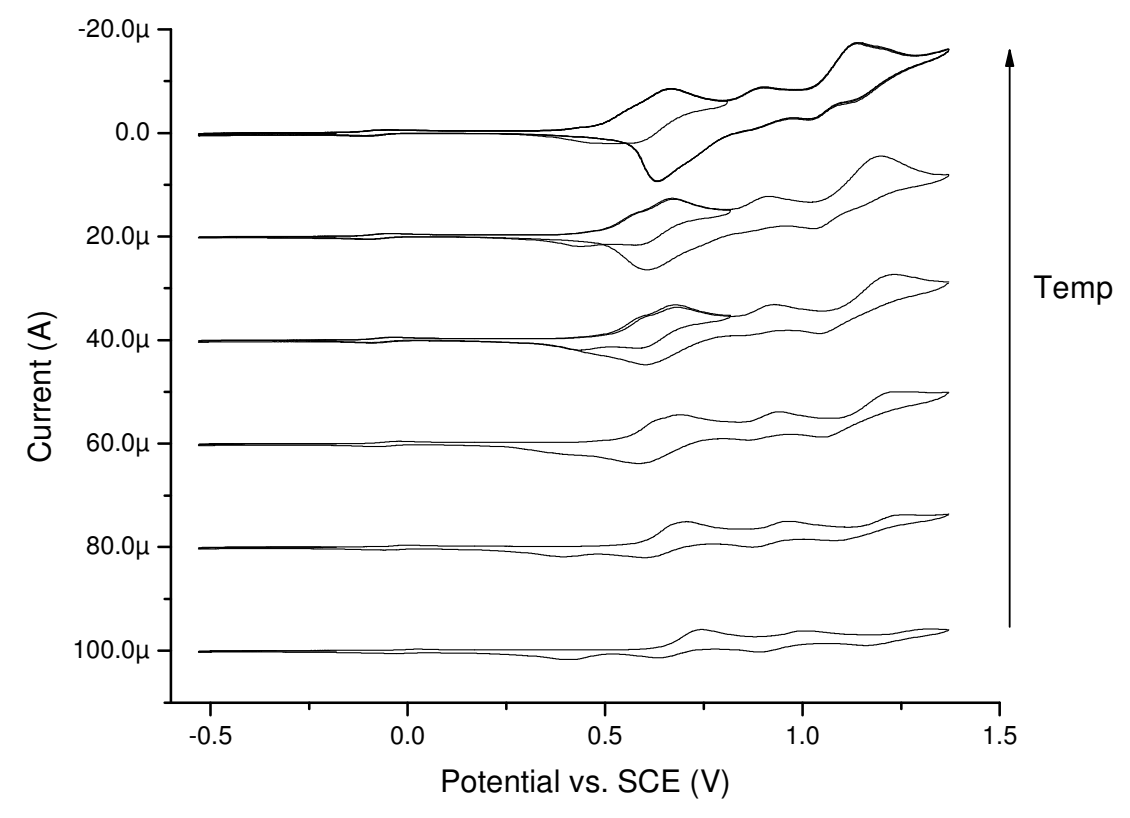

Figure S7. Oxidative electrochemistry of chloride analogue of $\mathbf{2 a}$ in DCM (0.1 M TBAPF 6$)$ at between $-80{ }^{\circ} \mathrm{C}$ and rt. scan rate $=25 \mathrm{mV} \mathrm{s}^{-1}$.

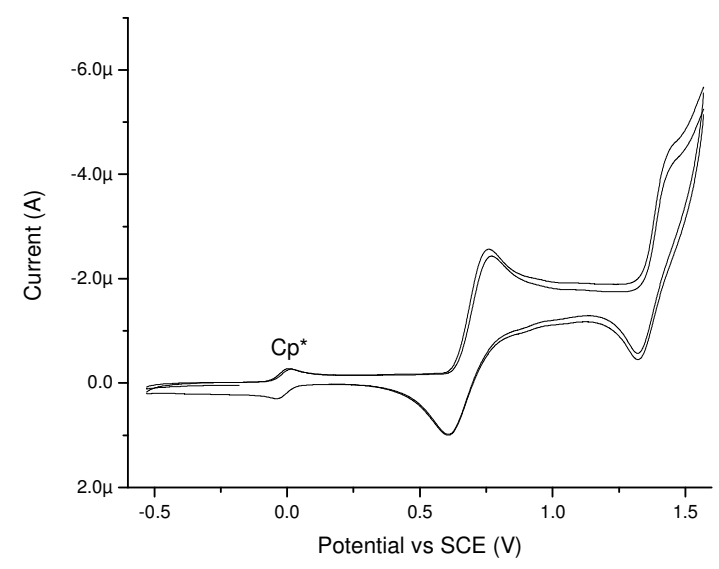

Figure S8. Oxidative electrochemistry of complex formed with $\mathbf{L 2}$ and $\mathrm{Cu}(\mathrm{I})\left[\mathrm{CH}_{3} \mathrm{CN}_{\mathrm{PF}}\right.$ in $\mathrm{CH}_{2} \mathrm{Cl}_{2}$ $(0.1 \mathrm{M} \mathrm{TBABr})$ at $-80{ }^{\circ} \mathrm{C}$. scan rate $=25 \mathrm{mV} \mathrm{s}^{-1}$. 


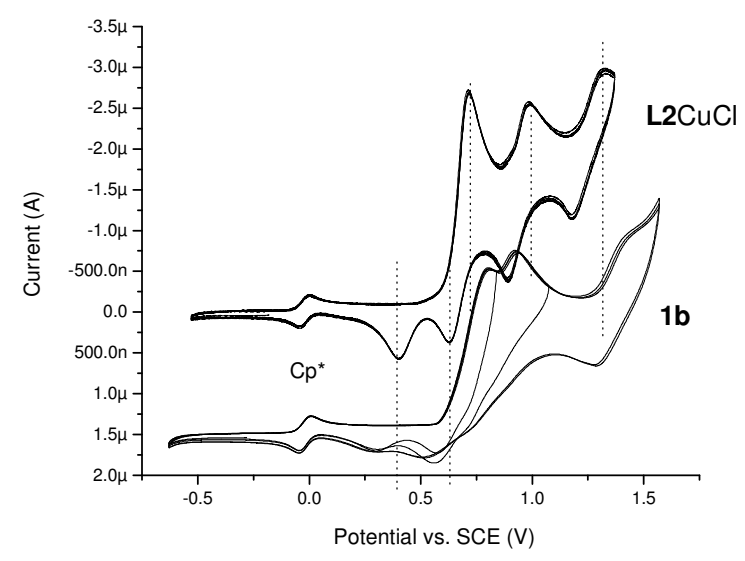

Figure S9. Oxidative electrochemistry of $\mathbf{1 b}$ and chloride analogue of $\mathbf{2 a}$.

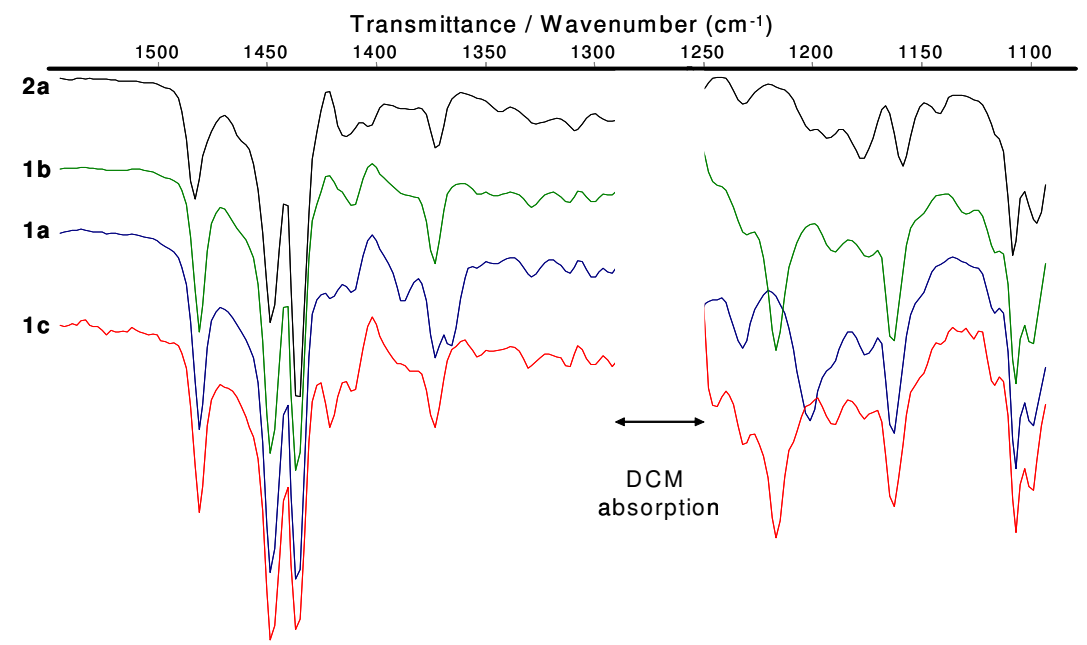

Figure S10. IR spectra for complexes 1a, 1b, 1c, 2a in $\mathrm{CH}_{2} \mathrm{Cl}_{2}$.

\section{Conjugate addition of EtMgBr to methyl crotonate.}

Solvent dependence. Solvent and halide dependent experiments were performed for the CA of EtMgBr to methyl crotonate $\mathbf{1 3}$ (Scheme S1). The choice of EtMgX as a Grignard reagent in this particular case was made due to very low reactivity of MeMgX towards CA to enoates (see ref. $6 \mathrm{c}$ in the article main text). CA of EtMgX to methyl crotonate appeared to be dependent on the solvent character and consequently on the Schlenk equilibrium in a similar manner to the one observed for the CA to enone $\mathbf{5}$ (see main text). For instance, the CA reaction performed in halogenated and ethereal solvents afforded high conversion and enantioselectivity $88-96 \%$ (Table S5, entries 1-4), (the regioselectivity was always 99\%). As it was observed for enones the reaction conditions directing the Schlenk equilibrium towards formation of $\mathrm{Et}_{2} \mathrm{Mg}$ caused significant drop in both enantioselectivity and conversion (entries 5-7). 


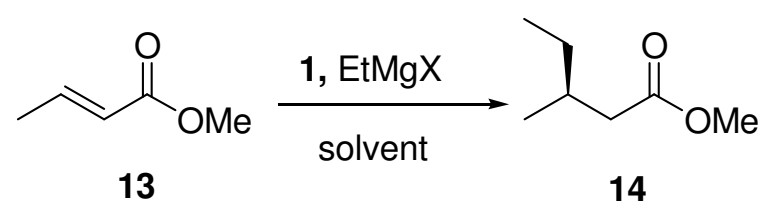

Table S5. CA of EtMgBr to $\mathbf{1 3}$ catalyzed by copper bromide complex $\mathbf{1 a}^{\mathbf{a}^{\mathrm{a}}}$

\begin{tabular}{cccc}
\hline Entry & Solvent & Conv. [\%] & ee [\%] \\
\hline 1 & $\mathrm{CH}_{2} \mathrm{Cl}_{2}$ & 92 & 94 \\
2 & toluene & 99 & 96 \\
3 & $t \mathrm{BuOMe}$ & 99 & 96 \\
4 & $\mathrm{Et}_{2} \mathrm{O}$ & 99 & 88 \\
5 & $\mathrm{THF}$ & 2 & 1 \\
$6^{\mathrm{c}}$ & $\mathrm{CH}_{2} \mathrm{Cl}_{2}$ & 36 & 86 \\
$7^{\mathrm{d}}$ & $\mathrm{CH}_{2} \mathrm{Cl}_{2}$ & 85 & 76
\end{tabular}

a Reaction conditions: reaction time $5 \mathrm{~h}, 130.35 \mathrm{M}, \mathrm{MeMgBr} 1.5$ equiv, $-78{ }^{\circ} \mathrm{C} .{ }^{\mathrm{b}}$ Conversion and enantioselectivity was determined by GC(chiral dex-CB column). ${ }^{c}$ Dioxane (1 equiv.) was added to the mixture of catalyst and $\mathrm{MeMgBr} \mathrm{CH} \mathrm{Cl}_{2}$ prior to addition of 13. ${ }^{\mathrm{d}} \mathrm{Me}_{2} \mathrm{Mg}$ and $\mathrm{Et}_{2} \mathrm{Mg}$ (1.5 equiv.) were used instead of $\mathrm{MeMgBr}$ and $\mathrm{EtMgBr}$ for these reactions.

Halide dependence. The reaction conversion and enantioselectivity of CA of EtMgX to crotonate 13 appeared to be dependent also on the halide identity (Table S6). For instance, high conversion and enantioselectivity were obtained for the addition of EtMgBr to $\mathbf{1 3}$, catalyzed by copper bromide complexes 1a, $\mathbf{1 b}$ and $\mathbf{1 c}$ (entries 1-3).

Table S6. CA of $\mathrm{RMgX}$ to 13 catalyzed by copper complex 1 in $\mathrm{CH}_{2} \mathrm{Cl}_{2}{ }^{\mathrm{a}}$

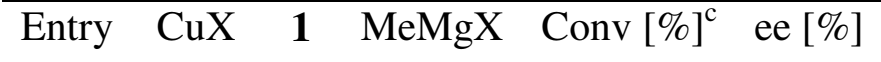

\begin{tabular}{cccccc}
\hline 1 & $\mathrm{CuBr}$ & $\mathbf{1 a}$ & $\mathrm{EtMgBr}$ & 92 & 94 \\
2 & $\mathrm{CuCl}$ & $\mathbf{1 b}$ & $\mathrm{EtMgBr}$ & 90 & 95 \\
3 & $\mathrm{CuI}$ & $\mathbf{1 c}$ & $\mathrm{EtMgBr}$ & 90 & 95 \\
4 & $\mathrm{CuBr}$ & $\mathbf{1 a}$ & $\mathrm{EtMgCl}$ & 96 & 80 \\
5 & $\mathrm{CuBr}$ & $\mathbf{1 a}$ & $\mathrm{EtMgI}$ & 40 & 40 \\
6 & $\mathrm{CuCl}$ & $\mathbf{1 b}$ & $\mathrm{EtMgCl}$ & 80 & 70 \\
7 & $\mathrm{CuI}$ & $\mathbf{1 c}$ & $\mathrm{EtMgI}$ & 50 & 88
\end{tabular}

${ }^{\mathrm{a}}$ Reaction conditions: reaction time $5 \mathrm{~h}$ for $13(0.35 \mathrm{M}), \mathrm{RMgBr} 1.5$ equiv., $-78{ }^{\circ} \mathrm{C}$. ${ }^{\mathrm{b}}$ Conversion (GC). ${ }^{\mathrm{c}}$ Regioselectivity is presented in brackets ${ }^{\mathrm{d}}$ Determined by GC (chiral dex-CB column). 
However, addition of EtMgCl and EtMgI to $\mathbf{1 3}$ catalyzed by $\mathbf{1 a}$ provided low enantioselectivity and moderate yield (entries 4,5). Similarly, low conversion and enantioselectivity were obtained for the CA of $\mathrm{EtMgCl}$ catalyzed by $\mathbf{1 b}$ (entry 6). The combination of EtMgI with copper iodide complex 1c afforded the product with relatively high enantioselectivity although conversion was still low (entry 7). 